\title{
SEKOLAH ISLAM TERPADU PRESPEKTIF MULTIDISIPLINER
}

\author{
Rio Kurniawan \\ Institut Islam Mamba'ul 'Ulum Surakarta \\ rio_msi@ymail.com
}

\begin{abstract}
The Integrated Islamic School (SIT) is currently one of the educational institutions that receives broad responses from the Indonesian Muslim community. That is evidenced by the increasing number of parents who send their children to various levels of SIT, from kindergarten, elementary school, junior high school to high school. At present there are thousands of Integrated Islamic Schools gathered under the auspices of the Integrated Islamic Schools Network (JSIT) and there are also many private schools developed by social and religious organization foundations in Indonesia called IT Schools and that follows the system.

Integrated Islamic Schools are essentially schools that implement the concept of Islamic education based on the Qur'an and Sunnah. This paper tries to answer some questions of the Integrated Islamic School through the perspective of History, Social and Politics and as a dissection knife from the Integrated Islamic School of Multidisciplinary Perspective and the Integrated Islamic School as a Renewal of the Islamic Education System
\end{abstract}

Keywords: Integrated Islamic School, Multidisciplinary

\section{Pendahuluan}

Munculnya berbagai lembaga pendidikan berlabel Islam di tanah air pada periode awal tahun 2000 memang cukup memberikan angin segar bagi para orang tua yang khawatir terhadap kondisi pergaulan putra - putrinya di bangku sekolah. Memang tidak kita pungkiri sebelumnya telah ada beberapa organisasi Islam yang juga menggarap ladang pendidikan ini secara kontinu. Namun kemunculan lembaga pendidikan berlabel Islam akhir-akhir ini yang semakin banyak dan tidak hanya dipegang oleh organisasi Islam tertentu agaknya memang hal tersebut berperan sebagai respon dari masyarakat yang membaik terhadap lembaga pendidikan berlabel Islam (sekolah Islam).

Sekolah Islam sebelumnya sempat mendapatkan stigma negatif dari masyarakat secara umum. Masyarakat menilai bahwa sekolah Islam adalah kasta kelas dua, jika putra-putrinya tidak masuk ke sekolah umum barulah mereka mau memasukkan putra- putri mereka ke sekolah Islam. Alih-alih untuk membuat putra-putri mereka lebih baik dengan menuntut ilmu di sekolah Islam, beberapa dari orang tua siswa masih berpikir, 
daripada tidak bersekolah, lebih baik di sekolahkan di sekolah yang Islam saja. Jikalau niatnya saja sudah seperti itu maka output yang dihasilkan sudah bisa kita tebak seperti apa nantinya.

Output pendidikan Islam yang sebenarnya dapat kita baca dari pengertian Ibnu Qayyim Al Jauziyah, beliau mengartikan pendidikan yang seringkali disebut dengan tarbiyah. Tarbiyah menurut beliau, mencakup tarbiyah qalb (pendidikan hati) dan tarbiyah badan secara sekaligus. Antara hati dan badan sama-sama membutuhkan tarbiyah. Keduanya harus ditumbuhkembangkan dan ditambah gizinya sehingga mampu tumbuh dengan sempurna dan lebih baik dari sebelumnya. ${ }^{76}$ Dengan pendidikan yang seimbang (tawazun) antara hati dan akal maka akan didapatkan kualitas sumber daya manusia yang luar biasa sesuai dengan ciri seorang muslim yang sempurna.

Sekolah Islam yang sekarang sudah mulai 'terasa' bedanya di masyarakat, penerimaan mereka terhadap sekolah Islam mulai meningkat, terutama pada sekolah Islam terpadu. Pengajaran di sekolah Islam terpadu yang cukup menarik membuat anak didik tidak jenuh dan lebih mengenal Islam dengan menyenangkan. Salah satu contohnya lewat berbagai permainan yang disisipi hikmah, mengajari hafalan dengan lagu anak-anak tidak lupa pula penyampaian cerita sejarah Islam dan para nabi dengan bermain peran dan lain sebagainya. Lebih menarik adalah pengajaran moral yang diterapkan dengan cara learning by doing dan juga diajarkan secara langsung oleh ustadz atau ustadzah mereka. Fokus utamanya adalah untuk membentuk akhlak yang Islami. ${ }^{77}$

Oleh karena itu dari uraian di atas, penulis ingin membahas lebih dalam kaitannya dengan Sekolah Islam Terpadu Prespektif Multidisipliner.

\section{Pembahasan}

Sebelum membahas lebih detail tentang Sekolah Islam Terpadu Prespektif Multidisipliner (Sejarah, Sosial, Politik), maka penulis sedikit memaparkan tentang definisi pendidikan dan pendidikan Islam. Dengan pendefinisian tersebut akan tercipta

\footnotetext{
Hal:46.

${ }^{76}$ Al-Jauziyah, Ibnu Qayim. 2011. Ighatsanu Lahfan min Mushahidis Syetan, (Kairo: tp, 1320H), Juz I,

${ }^{77}$ Fauziddin, Moh. 2009. Pembelajaran Agama Islam Melalui Bermain Pada Anak Usia Dini (Studi kasus di TKIT Nurul Islam Pare Kebupaten Kediri Jawa Timur), Hal:62.
} 
satu konsepsi dan persepsi tentang pendidikan dan pendidikan Islam yang intepretable, karena tergantung penekanan pendefinisiannya. Hal pertama dilakukan dalam memberi definisi tersebut adalah memaparkan definisi dari tokoh-tokoh yang selanjutnya penulis menyimpulkan pendapat para tokoh tersebut untuk mendapatkan definisi dari pendidikan Islam sebagai tema sentral dari pembahasan ini.

Menurut Crow and crow, seperti yang dikutip oleh Fuad Ihsan dalam bukunya "DasarDasar Kependidikan", mengatakan bahwa pendidikan adalah proses yang berisikan berbagai macam kegiatan yang cocok bagi individu untuk kehidupan sosialnya dan membantu meneruskan adat dan budaya serta kelembagaan social dari generasi ke generasi. ${ }^{78}$ Sedangkan dalam Undang-Undang SISDIKNAS tahun 2003, pendidikan diartikan sebagai usaha sadar dan terencana untuk mewujudkan suasana belajar dan proses pembelajaran agar peserta didik secara aktif mengembangkan potensi dirinya untuk memiliki kekuatan sepiritual keagamaan, pengendalian diri, kepribadian, kecerdasan, akhlak mulia, serta keterampilan yang diperlukan dirinya, masyarakat, Bangsa dan Negara. ${ }^{79}$

Sedangkan pendidikan Islam menurut Endang Saifuddin Anshori, seperti yang dikutip oleh Azyumardi Azra, adalah proses bimbingan (pimpinan, tuntutan, usulan) oleh subjek didik terhadap perkembangan jiwa (pikiran, perasaan, kemauan, intuisi dan sebagainya) dan raga objek didik dengan bahan-bahan tertentu pada jangka waktu tertentu dan dengan alat perlengkapan yang ada ke arah terciptanya pribadi tertentu disertai evaluasi sesuai dengan ajaran Islam. ${ }^{80}$

Sedangkan Muhammad S. A. Ibrahimy, sebagaimana yang di kutip oleh Syaiful dalam Laporan Penelitiannya, memberikan definisi bahwa pendidikan Islam adalah: Islamic education in the true sense of learn, is a system of education wich enables a man to lead his life according of the islamic ideology, so that he may easily mould his life accordence with tenets of Islam. ${ }^{81}$

\footnotetext{
${ }^{78}$ Fuad Ihsan. Dasar-Dasar Kependidikan. Jakarta: PT. Rineka Cipta. 2005. Hal: 4

${ }^{79}$ Undang-Undang SISDIKNAS (Sistem Pendidikan Nasional) 2003. Jakarta: Sinar Grafika.2003. Hal: 2

${ }^{80}$ Azyumardi Azra. Pendidikan Islam: Tradisi Dan Modernisasi Menuju Milenium Baru.Jakarta: PT. Logos Wacana Ilmu. 2002. Hal: 6

${ }^{81}$ Saiful, Tujuan Pendidikan Islam: Tinjauan Kritis Atas Pemikiran Muhammad 'Athiyah Al- Abrasyi (Laporan Penelitian). STAIN Jember. 1999. Hal: 10
} 
Maka dapat disimpulkan bahwa pendidikan Islam merupakan suatu sistem pendidikan yang membimbing peserta didik pada perkembangan jiwa dan raganya yang berideologi pada ajaran Islam yaitu al-Qur'an dan hadist.

Sekolah Islam Terpadu pada hakekatnya adalah sekolah yang mengimplementasikan konsep pendidikan Islam berlandaskan AlQur'an dan As Sunnah. Konsep operasional SIT merupakan akumulasi dari proses pembudayaan, pewarisan dan pengembangan ajaran agama Islam, budaya dan peradaban Islam dari generasi ke generasi. Istilah "Terpadu" dalam SIT dimaksudkan sebagai penguat (taukid) dari Islam itu sendiri. Maksudnya adalah Islam yang utuh menyeluruh, Integral, bukan parsial, syumuliah bukan juz'iyah. Hal ini menjadi semangat utama dalam gerak da'wah dibidang pendidikan ini sebagai "perlawanan" terhadap pemahaman sekuler, dikotomi, juz'iyah.

Dalam aplikasinya SIT diartikan sebagai sekolah yang menerapkan pendekatan penyelenggaraan dengan memadukan pendidikan umum dan pendidikan agama menjadi satu jalinan kurikulum. Dengan pendekatan ini, semua mata pelajaran dan semua kegiatan sekolah tidak lepas dari bingkai ajaran dan pesan nilai Islam. Tidak ada dikotomi, tidak ada keterpisahan, tidak ada "sekularisasi" dimana pelajaran dan semua bahasan lepas dari nilai dan ajaran Islam, ataupun "sakralisasi” dimana Islam diajarkan terlepas dari konteks kemaslahatan kehidupan masa kini dan masa deepan. Pelajaran umum, seperti matematika, IPA,IPS, bahasa, jasmani/kesehatan, keterampilan dibingkai dengan pijakan, pedoman dan panduan Islam. Sementara dipelajaran agama, kurikulum diperkaya dengan pendekatan konteks kekinian dan kemanfaatan, dan kemaslahatan.

SIT juga menekankan keterpaduan dalam metode pembelajaran sehingga dapat mengoptimalkan ranah kognitif, afektif dan konotif. Implikasi dari keterpaduan ini menuntut pengembangan pendekatan proses pembelajaran yang kaya, variatif dan menggunakan media serta sumber belajar yang luas dan luwes. Metode pembelajaran menekankan penggunaan dan pendekatan yang memicu dan memacu optimalisasi pemberdayaan otak kiri dan otak kanan. Dengan pengertian ini, seharusnya pembelajaran di SIT dilaksanakan dengan pendekatan berbasis (a) problem solving yang melatih peserta didik berfikir kritis, sistematis, logis dan solutif (b) berbasis kreativitas yang melatih peserta didik untuk berfikir orsinal, luwes (fleksibel) dan 
lancer fan imajinatif. Keterampilan melakukan berbagai kegiatan yang bermanfaat dan penuh maslahat bagi diri dan lingkungannya.

SIT juga memadukan pendidikan aqliyah, ruhiyah, dan jasadiyah. Artinya, SIT berupaya mendidik peserta didik menjadi anak yang berkembang kemampuan akal dan intelektualnya,meningkat kualitas keimanan dan ketaqwaannya kepada Allah SWT, terbina akhlak mulia, dan juga memiliki kesehatan, kebugaran dan keterampilan dalam kehidupannya sehari-hari.

SIT memadukan keterlibatan dan partisipasi aktif lingkungan belajar yaitu: sekolah, rumah dan masyarakat. SIT berupaya untuk mengoptimalkan dan sinkronisasi peran guru, orang tua dan masyarakat dalam proses pengelolaan sekolah dan pembelajaran sehingga terjadi sinergi yang konstruktif dalam membangun kompetensi dan karakter peserta didik . orang tua dilibatkan secara aktif untuk memperkaya dan memberi perhatian yang memadai dalam proses pendidikan putra - putri mereka. Sementara itu, kegiatan kunjungan ataupun interaksi keluar sekolah merupakan upaya untuk mendekatkan peserta didik terhadap dunia nyata yang ada ditengah masyarakat.

Dengan sejumlah pengertian diatas, dapatlah ditarik suatu pengertian umum yang komprehensif bahwa SIT adalah Sekolah Islam yang diselenggarakan dengan memadukan secara Integratif nilai dan ajaran Islam dalam bangunan kurikulum dengan pendekatan pembelajaran yang efektif dan pelibatan yang optimal dan koperatif antara guru dan orangtua, serta masyarakat untuk membina karakter dan kompetensi peserta didik. Demikian pengertian Sekolah Islam Terpadu menurut Kebijakan Standar Konsep Jaringan Sekolah Islam Terpadu (JSIT). Dan Selanjutnya Sekolah Islam Terpadu dapat ditinjau beberapa Perespektif.

\section{Sekolah Islam Terpadu Perespektif Sejarah}

Sejarah merupakan rekonstruksi masa lalu, yaitu merekonstruksi apa saja yang sudah dipikirkan, dikerjakan, dikatakan, dirasakan, dan dialami manusia. Namun, perlu ditegaskan bahwa membangun kembali masa lalu bukan untuk kepentingan masa lalu itu sendiri. ${ }^{82}$ Sejarah mempunyai kepentingan masa kini dan, bahkan, untuk masa yang akan datang. Oleh karenanya, orang tidak akan belajar sejarah karena tidak akan ada

\footnotetext{
${ }^{82}$ Kuntowijoyo. Pengantar Ilmu Sejarah. Yogyakarta: Yayasan Bentang Budaya. 1995. Hal: 17
} 
gunanya. Kenyataannya, sejarah terus di tulis, di semua peradaban dan di sepanjang waktu. Hal ini, sebenarnya cukup menjadi bukti bahwa sejarah itu sangat urgen. ${ }^{83}$

Menjelang abad ke 21, ada perubahan yang cukup menarik mengenai trend pendidikan (baca: pendidikan Islam) di Indonesia. Hal ini ditandai dengan lahirnya Sekolah-sekolah Islam Terpadu. Pada masa sebelumnya, model lembaga pendidikan di Indonesia hanya mengenal tiga model lembaga pendidikan yakni pesantren, madrasah, dan sekolah (umum). Sekolah (umum) merupakan lembaga pendidikan di Indonesia warisan penjajah Belanda yang mengajarkan ilmuilmu umum yaitu ilmu alam, ilmu sosial, dan humaniora. Pesantren merupakan lembaga pendidikan Islam tradisional dengan ciri khas di dalamnya terdapat masjid, kyai, santri, dan pengajaran kitab kuning. Pesantren, pada awalnya, hanya mengajarkan 100\% mata pelajaran agama dengan menggunakan referensi kitab kuning. Tujuan pendidikan di pesantren adalah untuk menghasilkan para ahli ilmu agama.

Madrasah merupakan tindak lanjut dari pendidikan di pesantren, yang mengajarkan $30 \%$ mata pelajaran agama, selebihnya mata pelajaran umum. Lebih dari

20 tahun terakhir, banyak pesantren telah mengadopsi sistem madrasah dan memasukkan mata pelajaran umum dalam sistem pendidikannya. Sistem madrasah diperkenalkan untuk menjembatani kesenjangan antara pesantren dan sekolah yang pada akhirnyamelahirkan dualisme dalam sistem pendidikan nasional. Dengan memberikan penekanan pada mata pelajaran-mata pelajaran agama, pesantren seringkali dianggap tidak mampu merespons kemajuan dan tuntutan zaman.

Pada dekade akhir tahun 1980-an, Sekolah Islam Terpadu mulai bermunculan. Diawali oleh para aktivis dakwah kampus yang tergabung dalam Lembaga Dakwah Kampus (LDK) Institut Teknologi Bandung (ITB), Universitas Indonesia (UI), dan beberapa universitas ternama lainnya yang tergabung dalam komunitas Jamaah Tarbiyah yang memiliki keprihatinan terhadap kondisi pendidikan di Indonesia. Mereka adalah para aktivis Islam kampus yang berperan penting dalam menyebarkan ideologi Islam kepada para mahasiswa. Kalangan pemuda menjadi target utama dari gerakan ini

${ }^{83}$ Ibid. Hal: 19. Dalam hal ini, Kuntowijoyo menjelaskan bahwa sejarah mempunyai nilai guna intrinsic: (1) sejarah sebagai ilmu, (2) sejarah sebagai cara mengetahui masa lampau, (3) sejarah sebagai penyataan pendapat, dan (4) sejarah sebagai profesi, sedangkan nilai guna ekstrinsik, yakni sebagai pendidikan: (1) moral, (2) Penalaran, (3) politik, (4) kebijakan, (5) perubahan, (6) masa depan, (7) keindahan, dan (8) ilmu bantu, selain berfungsi sebagai (9) latar belakang (10) rujukan, dan (11) bukti. 
karena mereka percaya bahwa para pemuda menjadi agen perubahan sosial yang sangat penting dalam melakukan islamisasi seluruh masyarakat Indonesia.

Tugas untuk menyiapkan generasi muda Muslim yang punya komitmen dakwah diyakini akan lebih efisien jika melalui pendidikan. Dalam konteks ini, mereka mendirikan Sekolah Islam Terpadu (SIT) Nurul Fikri dari tingkat Taman Kanak-kanak (TK) hingga Sekolah Menengah Atas (SMA) yang telah menginspirasi berdirinya Sekolah-Sekolah Islam Terpadu di seluruh wilayah Indonesia. Hingga saat ini, ada sekitar 1.000 Sekolah Islam Terpadu yang tergabung dalam Jaringan Sekolah Islam Terpadu (JSIT) yang kepengurusannya telah tersebar di seluruh wilayah Indonesia, dan ada sekitar 10.000 Sekolah Islam Terpadu yang secara struktural tidak bergabung di bawah JSIT. ${ }^{84}$

\section{Sekolah Islam Terpadu Perespektif Sosial}

Kehadiran Sekolah Islam Terpadu telah memberi warna baru terhadap perkembangan pendidikan di Indonesia. Bermula dari pendirian Sekolah Islam Terpadu Nurul Fikri Jakarta oleh para aktivis Masjid Kampus ITB dan UI yang terbagung dalam komunitas Jamaah Tarbiyah, lembaga pendidikan ini telah tersebar luas di negeri ini. Berbeda dengan tiga lembaga pendidikan lain, yakni pesantren, madrasah, dan sekolah umum, Sekolah Islam Terpadu ingin memadukan antara pendidikan agama yang menjadi cirikhas pesantren dan pendidikan modern yang menjadi cirikhas sekolah umum. Perbedaannya dengan madrasah, meskipun sama- sama memadukan antara pelajaran umum dan pelajaran agama, adalah Sekolah Islam Terpadu tidak hanya memadukan kedua jenis mata pelajaran tersebut dalam kurikulum formalnya saja, namun keduanya menyatu dalam satu kepribadian anak didik. Ditambah dengan fasilitas memadai yang mengakibatkan makin mahalnya biaya, mayoritas sekolah ini hanya dapat dijangkau oleh kalangan menengah Muslim. Sekolah ini juga mampu menampilkan corak baru mengenai reislamisasi masyarakat Muslim Indonesia.

Reislamisasi pada masa sebelumnya dilakukan di masjid-masjid dan melalui pengajian akbar, saat ini proses tersebut dilakukan melalui pembelajaran agama Islam di sekolah- sekolah.

${ }^{84}$ Suyatno, 2015, Sekolah Islam Terpadu Dalam Sistem Pendidikan Nasional, Al-Qalam Volume. III, Balai Penelitian dan Pengembangan Agama Makassar. Hal:3. 
Berdasarkan analisis data yang ditemukan di lapangan, penelitian ini menyimpulkan bahwa Sekolah Islam Terpadu merupakan bagian integral dari sistem pendidikan nasional di Indonesia. Hal ini tampak pada penggunamaan sekolah, kesediaan sekolah Islam terpadu untuk menerima sepenuhnya kurikulum yang berasal dari Kementerian Pendidikan dan Kebudayaan, pelaksanaan ujian yang menyesuaikan dengan ujian yang diselenggarakan oleh pemerintah, dan program sertifikasi oleh guru-guru di sekolah Islam terpadu.

Meskipun munculnya sekolah Islam terpadu merupakan respon atas ketidakpuasan terhadap praktek pendidikan di Indonesia, hingga saat ini, Sekolah Islam Terpadu tetap menjadi bagian integral dari sistem pendidikan nasional. Oleh karena itu, keberadaan Sekolah Islam Terpadu lebih tepat jika dikatakan sebagai upaya untuk melakukan islamisasi terhadap lembaga pendidikan formal di Indonesia. Islamisasi dilakukan terhadap semua komponen pendidikan, baik tujuan pendidikan, kurikulum, strategi, sumber belajar, hingga guru yang dianggap sebagai ujung tombak dalam pendidikan.

Jika dalam perkembangan sekolah ke depan tidak mampu memberi jawaban atas ketidakpuasan sebagian kalangan terhadap sistem pendidikan di Indonesia, bukankah berarti bahwa Sekolah Terpadu telah gagal mewujudkan cita-cita awal. Pesantren, madrasah, dan sekolah umum yang menjadi model lembaga pendidikan di Indonesia dianggap belum mampu mewujudkan tujuan pendidikan yang diidealkan oleh umat Islam. Bahkan untuk mewujudkan tujuan pendidikan nasional pun masih jauh dari harapan. Sebagaimana dinyatakan dalam Undang-undang No. 20 tahun 2003 tentang Sistem Pendidikan Nasional, tujuan pendidikan nasional adalah membentuk manusia yang beriman dan bertakwa kepada Tuhan Yang Maha Esa, berakhlak mulia, sehat, berilmu, cakap, kreatif, mandiri, dan menjadi warga negara yang demokratis serta bertanggung jawab. Namun demikian, Sekolah Islam Terpadu ternyata tidak mampu menjawab kritikannya sendiri. Alih-alih untuk melakukan perbaikan terhadap sistem pendidikan nasional, Sekolah Islam Terpadu justru masuk dalam satu habitat yang sama dengan lembaga pendidikan yang menjadi sasaran kritiknya. ${ }^{85}$

\section{Sekolah Islam Terpadu Perespektif Politik}

\footnotetext{
${ }^{85}$ Suyatno, 2015, Sekolah Islam Terpadu Dalam Sistem Pendidikan Nasional, Al Qalam Volume II, Balai Penelitian dan Pengembangan Agama Makassar, Hal:7.
} 
Sekolah Islam Terpadu menjadi sebuah fenomena dalam pendidikan kita. Pertama, secara historis memang bangsa Indonesia tidak akan pernah lepas dari nilai- nilai religius yang menjadi sumber dan daya kekuatan bangsa ini. Sesungguhnya yang memperjuangkan bangsa ini di garis depan adalah kaum santri yang siap berjuang dan berperang. Tapi, tidak semua ternyata memegang senjata, ada diplomat ulung seperti

K.H. Agus Salim, Guru dari para Founding Fathers kita HOS. Cokroaminoto, dua pendidir Ormas besar yang bertujuan untuk kemerdekaan bangsa, K.H. Hasyim Asy’ari (pendiri NU) dan K.H. Ahmad Dahlan (pendiri Muhammadiyah), negarawan seperti M. Natsir atau seorang tokoh militer bintang lima seperti Jenderal Soedirman dan begitu banyak lagi. Mereka adalah para tokoh pesantren dan santri yang berjuang berdasarkan kemampuan dan kapasitas masingmasing.

Kedua, pada dasarnya manusia selalu ingin kembali kepada fitrahnya. Allah SWT. telah menciptakan manusia sebagai makhluk terbaik diantara makhluk- makhluknya yang lain yang mampu berfikir. Kecenderungan manusia mempengaruhi apa pilihannya. Setelah sekian lama manusia Indonesia dicekoki dengan sistem sekuler walau disamarkan membuat jiwa bangsa ini memberontak. Upaya-upaya untuk mencerabut bangsa ini dari akar budayanya ternyata tidak berhasil. Masyarakat bosan dengan Sistem Pendidikan Nasional dan model pendidikan umum yang terus memisahkan antara pendidikan agama (Islam) dengan pendidikan umum. Itulah fitrah manusia yang ingin memenuhi relung jiwanya dengan cahaya Allah.

Ketiga, Sekolah Islam Terpadu menawarkan hal yang lebih dibandingkan dengan pendidikan umum. Selain mengintegrasikan pendidikan agama dengan pendidikan umum, Sekolah Islam Terpadu juga memberikan siswanya skill sesuai dengan bakatnya masingmasing. Selain itu, pola pembelajarannya juga sedikit berbeda dan memang mengakomodir hakhak siswa sebagai penuntut ilmu. Hal ini sebenarnya mencoba menjawab tantangan zaman yang ke depan akan masuk para era globalisasi dan perdagangan bebas. Anak-anak Indonesia harus sudah dibekali cara-cara manajerial, skill dan sebagainya yang menunjang dirinya untuk mampu bersaing. Tentunya membentuk karakter mereka bukan untuk menjadi tenaga kerja tetapi yang 
membuka lapangan kerja. Ketiga hal itulah yang membuat Sekolah Islam Terpadu sangat diminati oleh sekian banyak masyarakat Indonesia saat ini. ${ }^{86}$

Ketiga hal di atas bisa menjadi dasar untuk mencoba menerapkan sistem pembelajaran yang dilakukan di sekolah islam terpadu, sehingga tidak melulu nilai angka yang diprioritaskan. Tapi mulai mengarah kepada nilai akhlak yang dimiliki anak didik nantinya. Fakta di lapangan mengenai cara mendidik di sekolah umum sangat berbeda dengan sekolah Islam terpadu yaitu dalam 'mengolah' anak didik mereka menjadi sumber daya manusia yang juga pintar secara perilaku. Misalnya saja, tidak kita temukan semacam permainan berhikmah di sekolah umum, berdoa pun tidak bisa dilafalkan dan dibenarkan panjang pendek serta makhorijul hurufnya karena dalam 1 kelas mungkin ada siswa yang beragama lain. Selain itu, yang lebih penting adalah seluruh mata pelajaran mulai dari eksak sampai sosial disampaikan tanpa bisa terpadu dengan agama Islam, hanya sesuai dengan capaian tersampaikannya materi tersebut.

Menurut Suyatno dalam Disertasinya Sekolah Islam Terpadu (Genealogi, Ideologi, dan Sistem Pendidikan $)^{87}$

\section{Politisasi Pendidikan}

Sulit mengatakan bahwa tidak ada hubungan antara JSIT dengan PKS. Silahkan cek sendiri mulai dari para pengurus JSIT, pengurus Yayasan di tiap sekolah, hingga para guru dan karyawannya. Bila sudah begini jangan heran bila PKS punya hajat untukmengerahkan massa maka sekolah-sekolah ini akan mengerahkan baladanya untuk ikut terjun ke lapangan walau di saat jam kerja sekalipun, Padahal isyu yang diangkat banyak yang tidak berhubungan dengan dunia pendidikan, seperti pengerahan massa untuk pilkada, direct selling (istilah untuk menarik massa pemilih dengan cara door to door), Palestina, anti Amerika, dan lain-lain. Stiker, spanduk, baliho calon yang dukung dalam pilkadapun terkadang dapat ditemukan dengan mudah di dalam maupun di sekitar area sekolah. Sampai-sampai ada sebuah SDIT yang taglinenya kelewat maksa dengan mengambil kepanjangan dari PKS menjadi Pintar, Kreatif, Soleh. Luar biasa.

2. Mahal tapi tak sebanding dengan kesejahteraan karyawan

\footnotetext{
${ }^{86}$ Sumantri, Elly. 2011. Fenomena Madrasah Bubar Dan Islamic Full Day School. ${ }^{87}$ Suyatno, 2014, Sekolah Islam Terpadu (Genealogi, Ideologi, dan Sistem Pendidikan).Disertasi:Yogyakarta, Hal:77.
} 
Mahal itu subjektif, tapi bila harus merogoh kocek di atas 10 hingga 25 juta untuk uang pangkal dan SPP mendekati 1 jutaan per bulannya maka bagi sebagan besar masyarakat Indonesia harga tersebut jelaslah mahal. PKS boleh menyatakan sebagai partai yang memperjuangkan keadilan dan kesejahteraan. Tapi di lapangan, terutama di dunia pendidikan yang dikelola oleh para kader-kadernya hal tersebut jelaslah hanya sebuah ungkapan manis tanpa makna, alias sampah tak berguna. Sebab pada kenyataannya kerja keras guru dan karyawannya yang harus bekerja di atas 8 jam, bahkan harus ikut-ikutan pengerahan massa di arena pilkada segala tidak sebanding dengan gaji yang diterima. Dengan uang masuk dan SPP seperti di atas rata-rata gaji guru-guru SDIT hanya berkisar 1 hingga 2 juta an saja. Oleh karenanya tak heran biladi SDIT lalu lalang guru yang keluar masuk sangat tinggi. Dengan kondisi demikian bisa dibayangkan suasana belajar yang dirasakan oleh para siswa yang sering gonta ganti guru seperti.

3. Jadi kendaraan politik

Banyak para pemilik/pengurus yayasan yang menaungi Sekolah Islam Terpadu ini menjadi politisi berkat limpahan uang dari penyelenggaraan pendidikan ala Sekolah Islam Terpadu ini. Tak semuanya memang. Namun ulah oknum-oknum seperti ini ibarat orang yang menari di atas bangkai saudaranya sendiri. Di saat karyawan dan gurusedang kesusahan mereka malah bergelimang kemewahan.

\section{Kesimpulan}

Dari uaraian dalam pembahasan Sekolah Islam Terpadu Prespektif Multidisipliner yang mana mencoba menjawab melalui prespektif Sejarah, Sosial dan Politik dan sebagai pisau pembedah dari Sekolah Islam Terpadu Perespektif Multidisipliner sendiri, maka dapat disimpulkan sebagai berikut:

1. Sekolah Islam terpadu merupakan alternatif yang baik untuk mencetak anak didik yang cerdas secara akal dan juga hati. Orangtua yang khawatir akan kondisi masa depan akhlak putra-putrinya yang dalam hal ini dapat menentukan kondisi bangsa di masa depan dapat mulai untuk beralih sudut pandang mengenai pendidikan yang terbaik untuk buah hatinya. 
2. Melihat respon yang cukup baik dari masyarakat dan juga banyaknya bermunculan sekolah Islam terpadu, agaknya pemerintah juga perlu memberikan perhatiannya pada lembaga ini. Akan lebih baik lagi jika beberapa model pengajaran sekolah islam terpadu juga diterapkan pada pengajaran mata pelajaran di sekolah umum.

\section{Daftar Pustaka}

Al-Jauziyah, Ibnu Qayim . 2011. Ighatsanu Lahfan min Mushahidis Syetan Juz I,Kairo: tp, $1320 \mathrm{H}$

Azyumardi Azra, 2002, Pendidikan Islam: Tradisi Dan Modernisasi Menuju MileniumBaru.

Jakarta: PT. Logos Wacana Ilmu.

'Athiyah Al-Abrasyi, 1999 (Laporan Penelitian). STAIN Jember.

Fauziddin, Moh. 2009. Pembelajaran Agama Islam Melalui Bermain Pada Anak UsiaDini

(Studi kasus di TKIT Nurul Islam Pare Kebupaten Kediri Jawa Timur)

Fuad Ihsan, 2005, Dasar-Dasar Kependidikan. Jakarta: PT. Rineka Cipta. Kuntowijoyo, 1995,

Pengantar Ilmu Sejarah. Yogyakarta: Yayasan Bentang Budaya.

Undang-Undang SISDIKNAS (Sistem Pendidikan Nasional) 2003. Jakarta: SinarGrafika.

Saiful, Tujuan Pendidikan Islam: Tinjauan Kritis Atas Pemikiran Muhammad.Sumantri,

Elly. 2011. Fenomena Madrasah Bubar Dan Islamic Full Day School.

Suyatno, 2015, Sekolah Islam Terpadu Dalam Sistem Pendidikan Nasional, Al-QalamBalai

Penelitian dan Pengembangan Agama Makassar.

Suyatno, 2015, Sekolah Islam Terpadu Dalam Sistem Pendidikan Nasional, Al QalamBalai Penelitian dan Pengembangan Agama Makassar.

Suyatno, 2014, Sekolah Islam Terpadu (Genealogi, Ideologi, dan Sistem Pendidikan). :Yogyakarta: Disertasi UIN Sunan Kalijaga. 